Jurnal Lakon, 5 (1) 2016

(63-81)

\title{
KONSTRUKSI CITRA JOKO WIDODO DAN PRABOWO SUBIANTO DI DALAM PEMBERITAAN HARIAN BERBAHASA JEPANG THE DAILY JAKARTA SHINBUN PADA MASA KAMPANYE PEMILIHAN PRESIDEN INDONESIA 4 JUNI - 5 JULI 2014
}

The Image Construction of Joko Widodo and Prabowo Subianto in the Japanese Language Daily Newspaper The Daily Jakarta Shinbun during Presidential Election Campaign from June 4 to July 5 2014

\section{MOH. GANDHI AMANULLAH}

\author{
Program Studi Sastra Jepang \\ Fakultas Ilmu Budaya Universitas Airlangga \\ Jl. Dharmawangsa Dalam Selatan, Surabaya 60286 \\ e-mail: trigan2@yahoo.com
}

\begin{abstract}
Jakarta Shinbun is one of the largest, and the only Japanese language daily newspaper published in Indonesia. The head office is located in Jakarta and all of the editorial teams are Japanese journalists. Reader target of this daily are Japanese people living in Indonesia. Therefore, it could be predicted that it has a strong influence in shaping public opinion among Japanese living in Indonesia. At the time of Indonesian presidential election campaign from June 4 to July 5, 2014, Jakarta Shinbun (JS) published so many articles about campaign of two Indonesian presidential candidates, namely: Joko Widodo and Prabowo Subianto. This study aims to examine how the images of Joko Widodo and Prabowo Subianto were constructed in the news of Jakarta Shinbun during the presidential campaign. There are 56 articles to be examined, and to analyze them, the used methods are quantitative and qualitative approach by applying media content analysis, and discourse analysis. The result is known Prabowo Subianto was negatively imaged than Jokowi during the presidential election campaign of 2014. So it can be interpreted as well that this newspaper supported Joko Widodo more than another candidate during presidential election campaign.
\end{abstract}

Keywords: Content Analysis, Discourse Analysis, Mass Media, Teun Van Dijk, The Daily Jakarta Shinbun

Abstrak: Jakarta Shinbun adalah salah satu surat kabar yang terbesar, dan satu-satunya surat kabar harian berbahasa Jepang yang diterbitkan di Indonesia. Kantor pusatnya berlokasi di Jakarta dan semua tim editorial adalah jurnalis Jepang. Target pembaca surat kabar harian ini adalah orang Jepang yang tinggal di Indonesia. Oleh karena itu, dapat diprediksi bahwa ia memiliki pengaruh yang kuat dalam membentuk opini publik di antara orang Jepang yang tinggal di Indonesia. Pada saat kampanye pemilihan presiden Indonesia dari 4 Juni hingga 5 Juli 2014, Jakarta Shinbun (JS) menerbitkan begitu banyak artikel tentang kampanye dua kandidat presiden Indonesia, yaitu: Joko Widodo dan Prabowo Subianto. Penelitian ini bertujuan untuk mengkaji bagaimana citra Joko Widodo dan Prabowo Subianto dikonstruksi dalam berita Jakarta Shinbun selama kampanye presiden. Ada 56 artikel yang akan dipelajari, dan untuk menganalisisnya, metode yang digunakan adalah pendekatan kuantitatif dan kualitatif dengan menerapkan analisis isi media, dan analisis wacana. Hasilnya menunjukkan bahwa Prabowo Subianto dicitrakan secara negatif dibandingkan dengan Jokowi selama kampanye pemilihan presiden tahun 2014. Sehingga dapat ditafsirkan juga

Jurnal Lakon: Kajian Sastra dan Budaya 
bahwa surat kabar ini lebih mendukung Joko Widodo daripada kandidat lain selama kampanye pemilihan presiden.

Kata-kata Kunci: Analisis Isi, Analisis Wacana, Media Masa, Teun Van Dijk, The Daily Jakarta Shinbun

\section{PENDAHULUAN}

Pemilu Presiden (pilpres) tahun 2014 merupakan salah satu pilpres paling fenomenal dan dinamis sepanjang penyelenggaraan pemilu presiden di Indonesia. Dibandingkan dua pemilu presiden sebelumnya tahun 2004 dan 2009, hampir seluruh perhatian masyarakat Indonesia dari Sabang sampai Merauke tersedot pada perhelatan yang diadakan lima tahun sekali. Masyarakat yang pada pemilihan presiden sebelumnya tidak pernah menggunakan hak suaranya, seolah mendapatkan momentum untuk tidak menyianyiakan suaranya pada pemilu kali ini.

Salah satu yang memicu panasnya suhu politik ialah karena munculnya salah satu kandidat capres di luar prediksi, yaitu Joko Widodo alias Jokowi. Bila pada pemilu presiden sebelumnya, para calon berasal dari para elit partai yang cukup popular, atau setidaknya sudah pernah duduk di pemerintahan, kali ini capres Jokowi bukanlah berasal elit partai maupun bagian dari elit pemerintah. Jokowi adalah kader partai dari kalangan biasa, yang karena kepopulerannya membuat PDI-P menganggap ia yang paling berpeluang besar bersaing dengan calon presiden lainnya, yaitu Prabowo Subianto.

Situasi ini memicu masyarakat melihat ada sesuatu yang baru, berbeda dari pemilu-pemilu sebelumnya. Bagi masyarakat yang pada pilpres-pilpres sebelumnya tidak pernah menggunakan hak suaranya saat pemilu, mulai berpikir untuk menggunakannya. Masyarakatpun menjadi terbelah menjadi dua kubu yaitu; yang pro capres Jokowi dan yang pro capres Prabowo Subianto.

Media massa adalah salah satu entitas dalam kehidupan masyarakat yang turut terbelah. Berdasarkan laporan KPI yang dilansir dalam artikel media online BBC Indonesia, Kubu Prabowo-Hatta didukung Aburizal Bakrie (pemilik media TV One), dan Hary Tanoesoedibjo (pemilik media di bawah naungan MNC Group (RCTI, MNC TV, Global TV, dll)). Sementara itu, kubu Jokowi-Kalla didukung oleh Surya Paloh (pemilik Media Indonesia Group (Metro TV) ${ }^{1}$. Media massa lainnya: Kompas, Tribun News, Jawa Pos (mendukung Jokowi-Kalla), dan Republika (mendukung Prabowo-Hatta).

Dukung mendukung capres tersebut memanas ketika memasuki masa kampanye pemilihan presiden tanggal 4 Juni - 5 Juli 2014. Selama sebulan media massa berlomba membentuk opini publik agar pembaca mendukung capres yang didukungnya. Ironisnya, tajamnya persaingan dalam dukung-mendukung, justru membuat beberapa media massa tidak menghiraukan lagi prinsip-prinsip jurnalistik yang baik dalam mengkonstruksi berita.

http://www.bbc.com/indonesia/berita_indonesia/2
014/07/140702_lapsus_media_bias)

Jurnal Lakon: Kajian Sastra dan Budaya e-ISSN: 2527-4899; p-ISSN 2252-8954 
Banyak berita yang ditampilkan tak lagi berimbang. Bahkan bagaimana sikap dan tendensi media ke salah satu calon yang didukung tampak vulgar terlihat. Calon presiden yang didukungnya dicitrakan positif bahkan berlebihan, sementara calon presiden lawannya dicitrakan negative, yang tak kalah berlebihan pula. Media yang mestinya menampilkan berita yang obyektif, tanpa tendensi, dan berimbang, tampak terjebak dan bias dalam dalam kontestasi kampanye para capres. Apa yang menarik adalah, jika media massa di Indonesia telah terbelah menjadi dua kubu, maka perlu ditilik bagaimana sikap media asing khususnya yang berbasis di Indonesia.

Media massa asing dengan target pembaca orang asing dapat dihipotesakan akan jauh lebih netral dan obyektif daripada media massa lokal karena target pembacanya adalah orang asing, yang notabene bukan calon pemilih. The Daily Jakarta Shinbun (JS) adalah salah satu media massa asing berbentuk surat kabar cetak dan online berbahasa Jepang yang berbasis di Indonesia. Pembacanya adalah para pembaca yang harus bisa membaca kanji dan itu adalah orang Jepang.

Bila dikaitkan dengan latar belakang kondisi di atas, dapat dimunculkan hipotesa bahwa The Daily Jakarta Shinbun lebih obyektif dalam mengkonstruksi citra sosok Jokowi dan Prabowo pada masa kampanye pemilihan presiden 2014. Namun jika benar demikian, perlu dipertanyakan apakah media massa asing yang notabene bukan media massa lokal dapat memberitakan pilpres lebih obyektif dan tidak terjebak dalam dukung-mendukung capres. Pertanyaan-pertanyaan inilah yang akan coba diteliti lebih lanjut dalam penelitian ini. Berdasarkan latar belakang di atas, maka penelitian ini bertujuan untuk menjawab bagaimana The Daily Jakarta Shinbun mencitrakan sosok Prabowo dan Jokowi pada masa kampanye pemilihan presiden RI dari tanggal 4 Juli - 5 Juli 2014

\section{METODE PENELITIAN}

Penelitian ini adalah penelitian media, yaitu dengan menjadikan surat kabar sebagai obyek untuk diteliti dengan tujuan menjawab permasalahan yang diangkat. Metode penelitian yang penulis gunakan adalah dengan metode deskriptif analitis dengan pendekatan kualitatif. Langkah-langkah yang dilakukan adalah sebagai berikut: Pertama, mengumpulkan bahan berupa artikel berita yang diterbitkan secara cetak oleh The Daily Jakarta Shinbun pada alamat URL: www.jakartashinbun.com. Artikel cetak lama didapatkan melalui URL tersebut dengan berbayar. Periode pengambilan data dibatasi yaitu artikel yang terbit hanya pada masa kampanye pemilihan presiden 2014 yaitu pada tanggal 4 Juni - 5 Juli 2014. Untuk menemukannya digunakan kata kunci “ジョコウィ” (Jokowi)、dan “プラボ ウォ“ (Prabowo) yang dimasukkan ke dalam URL tersebut. Dari hasil pencarian ditemukan 56 artikel yang membahas Jokowi dan Prabowo pada periode kampanye tersebut. Artikel-artikel inilah yang dijadikan data primer untuk dianalisis.

Periode pengambilan data dibatasi pada periode tersebut dilatari alasan bahwa masa kampanye adalah periode paling sensitif dalam pemilu presiden, sehingga menjadi periode paling menantang dan periode "ujian" bagi media massa untuk sejauh mana media massa menampilkan berita secara oyektif, berimbang. Kedua, untuk membuktikan apakah mereka benarbenar menjaga prinsip-prinsip jurnalistik

Jurnal Lakon: Kajian Sastra dan Budaya 
yang baik atau justru terjebak dalam kontestasi pemilu capres.

Kedua, data primer yang telah terkumpul lalu dianalisis, pertama dengan menggunakan metode analisis isi (content analysis) dan kedua dengan menggunakan metode analisis wacana (kritis) yang meminjam model analisis wacana Teun Van Dijk. Analisis isi dilakukan dalam bentuk mencari topik, tema dari masing-masing paragraf dari tiap-tiap artikel pada 53 artikel. Tujuannya untuk mengetahui isu apa yang diangkat pada tiap-tiap artikel dan mencari citra capres Jokowi dan Prabowo dikonstruksi oleh JS. Tema/topik/isu pada masing-masing artikel yang telah didapat kemudian dianalisis dengan cara diinvetarisir, digeneralisasi, dan diinterpretasikan.

Analisis wacana dilakukan dalam bentuk analisis satu atau dua artikel yang dipilih dengan menggunakan model analisis Van Dijk. Metode ini digunakan dengan tujuan sama, yaitu untuk mengetahui bagaimana Jokowi dan Prabowo diberitakan dan dicitrakan oleh JS, terutama untuk membongkar hal-hal yang sifatnya laten, tersembunyi, sesuatu di balik yang manifest (tampak) seperti maksud, citra, dan lain- lain. Peneliti mencoba meminjam model analisis wacana Van Dijk namun hanya difokuskan pada analisis dimensi teks saja. Sementara itu, dari 53 artikel, pemilihan artikel/teks dilakukan secara random, bebas, dan jenis teks yang dipilih adalah artikel berjenis straight news JS. Ketiga, hasil analisis selanjutnya disimpulkan dan digunakan menjawab pertanyaan yang telah dirumuskan di dalam rumusan masalah.

I. Sekilas Profil Jokowi dan Prabowo
Profil Jokowi

Joko Widodo atau akrab disebut dengan Jokowi lahir di Solo, 21 Juni 1951. Karir politiknya bermula ketika ia terpilih sebagai Wali Kota Solo periode 2005-2010. Karena kinerjanya yang baik, Jokowi kembali terpilih untuk memimpin masyarakat Solo pada periode 2010-2015. Partai Demokrasi Indonesia Perjuangan (PDIP) kembali mengusungnya maju dalam pemilihan kepala daerah (Pilkada) DKI Jakarta 2012 sebagai gubernur.

Jokowi berpasangan dengan calon wakil gubernur Basuki Tjahaja Purnama akhirnya berhasil unggul dari lawan politiknya pada waktu itu yakni Fauzi Bowo (Cagub) dan Nachrowi Ramli (Cawagub) dengan perolehan suara sebanyak 2.472.130 suara atau 58.82 persen $^{2}$. Jokowi dan Ahok resmi dilantik sebagai Gubernur dan Wakil Gubernur DKI Jakarta periode 2012-2017 pada 15 Oktober 2015.

Menjabat kurang dari dua tahun, PDIP mengusulkan Jokowi untuk maju dalam pemilihan presiden sebagai calon presiden (Capres) dan didampingi oleh Jusuf Kalla sebagi calon wakil presiden (Cawapres). Hasil dari pemilu presiden 2014, KPU menetapkan hasil perolehan Jokowi-Kalla sebanyak 53,15 persen suara atau sebanyak 70.633.576 suara dan mengungguli pasangan Prabowo-Hatta. Hasil tersebut berdasarkan penghitungan suara di 33 provinsi dengan jumlah suara sah sebanyak 132.896 .438 suara $^{3}$. Jokowi

\footnotetext{
2 (http://metro.news.viva.co.id/news/read/354702ini-rekapitulasi-hasil-suara-pilkada-dki- putaran-2)

${ }^{3}$ http://www.bbc.com/indonesia/berita_indonesia/ 2014/07/140722 KPU hasil pilpres
} 
resmi dilantik menjadi Presiden Republik Indonesia pada 20 Oktober 2014.

\section{Profil Prabowo}

Prabowo Subianto atau yang sering disebut dengan Prabowo lahir di Jakarta, 17 Oktober 1951. Ia menempuh pendidikan dan jenjang karir militer selama 28 tahun sebelum berkecimpung di dunia bisnis dan politik. Prabowo memulai karir militernya sejak mengenyam pendidikan di Akademi Militer Magelang pada tahun 1970 dan lulus pada tahun 1974. Pada tahun 1998, Prabowo dilantik sebagai Panglima Komando Cadangan Strategi TNI Angkatan Darat (Pangkostrad).

Meski karir militernya cemerlang, Prabowo sering dikaitkan dengan dugaan pelanggaran Hak Asasi Manusia. Tudingan yang dialamatkan kepadanya yakni kasus penculikan aktivis dan penembakan mahasiswa Trisakti, penyulut kerusuhan Mei 1998 dan menerabas isu klik dan intrik di kalangan elite ABRI.

Pada tahun 2004 Prabowo mengikuti konvennsi pemilihan capres Partai Golkar, namun kalah dari mantan atasannya Wiranto. Kekalahannya membuat Prabowo mendirikan partai baru yakni Partai Gerakan Indonesia Raya Gerindra, dan mendampingi Megawati Sukarnoputri sebagai calon wakil presiden pada pilpres tahun 2009 lalu. Pada pilpres tersebut, Prabowo gagal, namun masih berambisi menjadi orang nomor satu RI.

Demi mewujudkan usahanya menjadi pemimpin RI, pada pilpres 2014, dia menjalin koalisi dengan partai yang menjadi kendaraan politik Suharto yakni partai Golkar, tiga partai Islam; PPP, PKS dan PAN, dan terakhir partai Demokrat.
Kemudian Prabowo menggandeng Hatta Rajasa, mantan mentri koordinator perekonomian kabinet SBY 2004-2009 sebagai cawapres. Hasilnya pada pemilu presiden tahun 2014 perhitungan suara KPU pada 22 Juli 2014 menyatakan pasangan Prabowo-Hatta kalah dari pasangan Jokowi- Kalla dengan meraih $46,85 \%$ atau 62.262.844 suara. Prabowo pun memutuskan untuk mundur dari Pilpres 2014 sehingga Jokowi menang dalam Pilpres 2014.

\section{Profil The Daily Jakarta Shinbun}

The Daily Jakarta Jakarta Shinbun (じやかるた新聞) adalah satu-satunya surat kabar berbahasa Jepang berbasis di Indonesia. Surat kabar ini secara resmi didirikan pada 16 November 1998. Pendirinya, Yasuo Kusano, seorang veteran koran Jepang Mainichi Shinbun. Tujuan didirikannya harian ini adalah adanya keinginan menyampaikan informasi secara akurat tentang Asia ke Jepang. Yasuo Kusano merasakan adanya kebutuhan memberikan informasi yang akurat kepada Jepang tentang politik dan budaya Indonesia serta berita bagi warga negara Jepang di Indonesia 4 .

Secara singkat profil The Daily Jakarta Shinbun edisi cetak adalah sebagai berikut:

Nama Surat Kabar : じやかるた新聞 atau The Daily Jakarta Shinbun

Berdir Sejak : : 16 November 1998 Target Pembaca : WN Jepang, Pekerja Lokal, serta Wirausahawan dan keluarganya, serta WNI yang mempelajari bahasa Jepang

4

http://www.thejakartapost.com/news/2009/11/30 /jakarta-shimbun039-a-bridge- indonesia.html

66

Jurnal Lakon: Kajian Sastra dan Budaya e-ISSN: 2527-4899; p-ISSN 2252-8954 


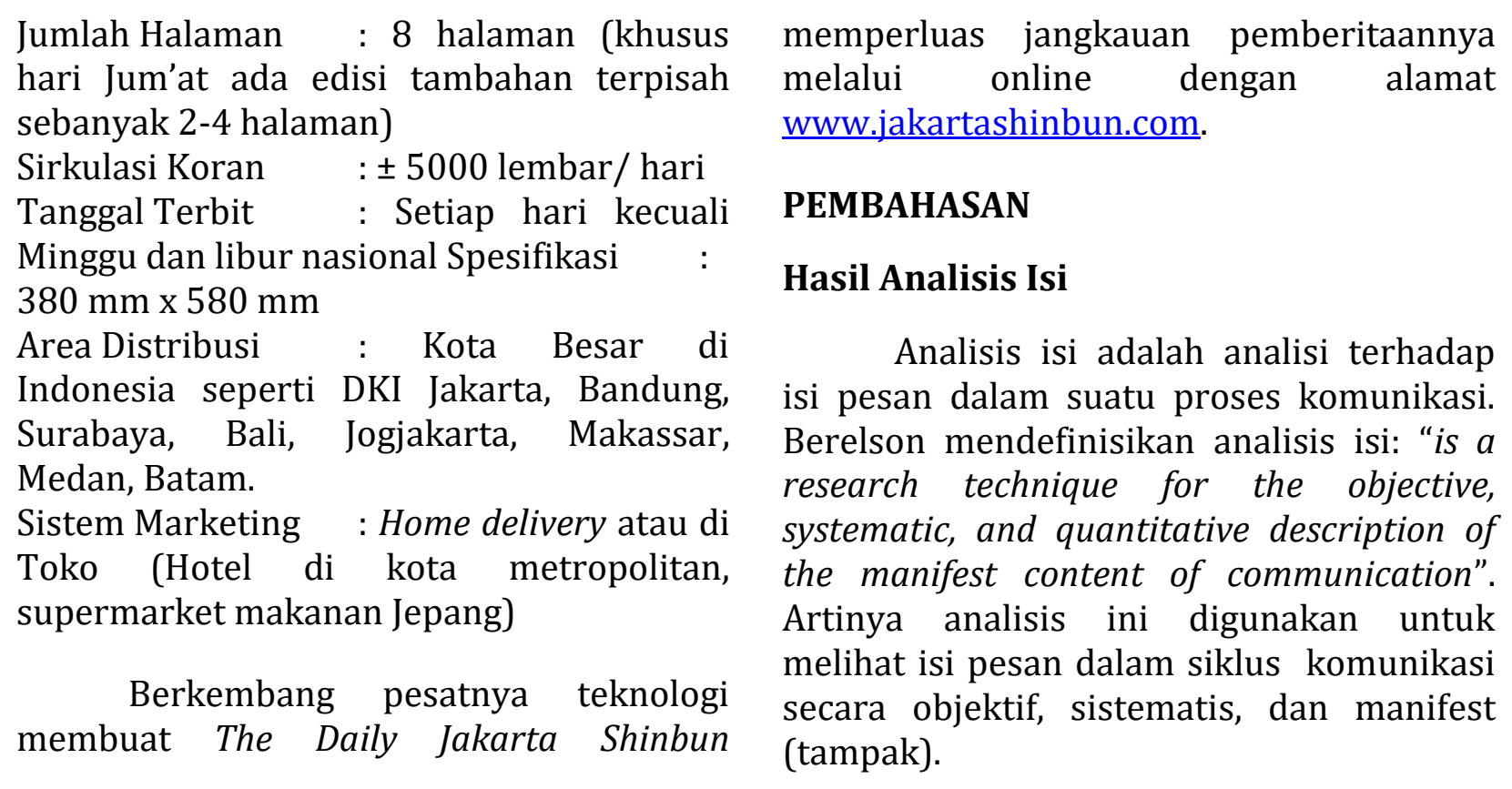


Dalam penelitian ini analisis isi digunakan untuk melihat isi atau topik pesan yang disampaikan oleh masing masing artikel JS yang terbit selama masa kampanye pilpres 2014. Dengan diketahuinya isi dari masing-masing artikel secara keseluruhan diharapkan akan
Melalui pembacaan mendalam terhadap 56 artikel, dan pencarian isu yang diangkat pada tiap paragraph dari masingmasing artikel, didapatkan 80 tema/topik yang diangkat dari keseluruhan 56 artikel tersebut seperti di bawah ini mengenai Isu/Topik pada 56 Artikel Jakarta Shinbun

\begin{tabular}{|l|c|l|}
\hline Isu/ Topik & Jumlah & Afiliasi \\
\hline cuti birokrasi negara sebagai tim sukses & 2 & Netral \\
\hline dana pemilu capres dan atau partai & 2 & Netral \\
\hline debat jokowi prabowo & 4 & Jkw-Pra \\
\hline dukungan ormas agama pada Jokowi & 1 & Jkw \\
\hline dukungan ormas agama pada prabowo & 1 & Pra \\
\hline dukungan parpol pada prabowo & 1 & Pra \\
\hline fakta negatif Jokowi & 2 & Jkw \\
\hline fakta negatif Prabowo & 12 & Pra \\
\hline harapan MK & 1 & Netral \\
\hline hasil survey opini public & 8 & Netral \\
\hline janji politik Jokowi & 5 & Jkw \\
\hline janji politik prabowo & 5 & Pra \\
\hline kampanye negatif terhadap Jokowi & 8 & Jkw \\
\hline kampanye positif terhadap Jokowi & 3 & Jkw \\
\hline kampanye positif terhadap prabowo & 1 & Jkw \\
\hline kegiatan/kampanya prabowo & 3 & Pra \\
\hline kegiatan/kampanye hatta & 1 & Pra \\
\hline kegiatan/kampanye Jokowi & 5 & Jkw \\
\hline kekayaan capres & 1 & Netral \\
\hline ketidaknetralan media massa dalam kampanye pilpres & 2 & Netral \\
\hline korupsi hambalang & 1 & Netral \\
\hline laporan kekayaan capres & 1 & Netral \\
\hline medsos dan pilpres & 2 & Netral \\
\hline penyimpangan kampanye prabowo & 2 & Pra \\
\hline perlunya netralitas TNI, polri, birokrasi & 1 & Netral \\
\hline peta dukungan di ln & 1 & Netral \\
\hline Peta dukungan pesantren & 1 & Netral \\
\hline peta kekuatan pendukung JKW Prabowo & 1 & Jkw Pra \\
\hline teknis pilpres & 2 & Netral \\
\hline dketahul & & \\
\hline
\end{tabular}

diketahui porsi pemberitaan, kecenderungan isi pemberitaaan, sehingga dari situ dapat dideteksi bagaimana pemberitaan Prabowo dan Jokowi dikonstruksi. yang Terkait dengan Jokowi dan Prabowo Selama Masa Kampanye Pilpres 4 Juni - 5 Juli 2016.

Dari tabel di atas diketahui bahwa isu/topik yang terkait dengan Prabowo 
terdapat 31 topik, dan yang terkait dengan Jokowi sebanyak 29 topik. Ini menandakan dari sisi jumlah isu/topik yang diangkat, JS cukup berimbang dalam memberitakan baik Prabowo maupun Jokowi karena hanya berselisih dua tema saja.

Namun, bila ditilik isi dari isu tersebut, dari 31 isu tentang Prabowo, terdapat 14 isu yang mencitrakan negatif Prabowo yang terdiri dari isu tentang "fakta negatif tentang Prabowo" yaitu terdapat 12 isu, dan tema "penyimpangan kampanye Prabowo" sebanyak 2 isu. Contoh dari isuisu tersebut diantaranya adalah sebagai berikut:

- Prabowo dituduh melakukan penculikan aktivis 1998.

- Prabowo terlibat dalam kerusuhan 1998.

- Prabowo melanggar HAM.

- Prabowo dipecat dari militer

- Prabowo kesukaan Amerika

- Tokoh-tokoh dalam koalisinya terlibat korupsi. dan lain-lain.

Contoh cuplikan isu tentang "fakta negatif tentang Prabowo" di atas:

$$
\text { ジョコウィ陣営のウィラント元国 }
$$

軍司令官・元国防相がプラボウォ元陸軍 特殊部隊司令官が $1997 \sim 98$ 年の活 動家拉致（1 3 人行方不明、1 人死亡） を国軍司令部の指令ではなく、自ら指揮 していたと明らかにしたことをめぐり、 プラボウォ大統領候補は 20 日、地元紙 に対し「答える必要はない」と回答しし た。

Mantan Pangab ABRI Wiranto yang merupakan kubu Jokowi, sibuk menjelaskan bahwa Prabowo, Komandan Jenderal Kopasus melakukan penculikan aktivis 1997- 98 (1 tewas, dan 31 menghilang) bukan atas perintah Markas ABRI melainkan atas instruksi pribadi, dan Calon Presiden Prabowo menjawab pada media lokan "hal itu tak perlu ditanggapi" (Jakarta Shinbun 21 Juni 2014).

Contoh cuplikan "penyimpangan kampanye Prabowo"

中央ジャカルタの国軍所属機関が 有権者を戸別訪問し、来月9日投票の大 統領選でグリンドラ党の プラボウォ 候補 に投票するよう要請した疑いが浮上し た。

Muncul kecurigaan bahwa Babinsa Jakarta Pusat berkunjung dari rumah ke rumah, dan meminta agar mencoblos Prabowo dari Partai Gerindra pada tanggal 9 hari pencoblosan bulan depan Uakarta Shinbun, 9 Juni 2014).

Selanjutnya, terkait dengan Jokowi, bila dibandingkan dengan Prabowo, isu yang mencitrakan negatif Jokowi hanya 2 isu saja, yaitu yang terkait dengan isu "fakta negatif tentang Jokowi". Terdapat tema tentang Jokowi yang seolah mencitrakan negatif Jokowi yaitu tema "kampanye negatif terhadap Jokowi”, namun isinya adalah berita fitnah dan kampanye hitam yang menerpa dirinya. Seolah memang mencitrakannya negatif, tetapi yang terjadi sebaliknya, karena akan membuat pembaca yang membacanya justru akan menaruh simpati padanya. Jadi bila dibandingkan dengan tema negatif tentang Prabowo yang jumlahnya 14 isu, isu negatif tentang Jokowi jauh lebih sedikit yaitu hanya dua saja sehingga berselisih 10 isu dengan Prabowo.

Contoh isu tentang "fakta negatif tentang Jokowi" adalah sebagai berikut: 
グリンドラ党の ハシム 顧問会副会 長（プラボウォ 大統領候補の弟） は3 日、研究機関での講演で「ジョコウィ 氏 （大統領候補）に 1 年半だまされた」と 語った。選挙戦を4 日に控え、すぐさま ネガティブキャンペーンをしかけた。こ れに対して ジョコウィ 氏は同日、「寄付 は選対に入らず、プラボウォ 氏の個人的 なコマーシャルに使われた」と否定。

Pada tanggal 3, Hasyim wakil katua Pembina Partai Gerindra (adik dari capres Prabowo) dalam sebuah kuliah umum lembaga penelitian mengatakan "tertipu oleh Jokowi (capres) selama satu tahun setengah". Mengenai hal ini, pada hari yang sama Jokowi membantah bahwa sumbangan dana pemilu digunakan untuk iklan pribadi Pak Prabowo" (Sebelum kutipan ini ada komentar dari Hasyim bila selama kampanye pemilihan Gubernur DKI, Jokowi disumbang oleh Hasyim, dan ternyata ia meninggalkan jabatan gubernur untuk menjadi presiden) (Jakarta Shinbun, 4 Juni 2014).

Kesimpulan kecil yang dapat diambil ialah, bahwa melalui analisis isi artikel, porsi tema tentang Prabowo dan Jokowi terlihat diangkat secara berimbang. Namun bila ditilik isinya, JS tampak menampilkan isu yang mencitrakan negatif Prabowo jauh lebih banyak yaitu sebanyak 14 tema, daripada Jokowi yang hanya 2 tema saja. Dari sini sedikit banyak telah dapat diraba bagaimana sikap dan kenetralan JS, bahwa media ini tampak lebih mendiskreditkan Prabowo daripada Jokowi, yang bisa diinterpretasikan lebih pro kepada Jokowi.

\section{Hasil Analisis Wacana}

Analisis wacana digunakan untuk mengetahui sesuatu yang tersembunyi dari teks, sesuatu yang tak tampak secara empiris dalam suatu teks (wacana). Dalam sebuah komunikasi pengirim pesan tidak selalu memperlihatkan maksud, preferensi, dan sikapnya secara eksplisit ke dalam teks. Dalam banyak kasus melalui rekayasa wacana mereka menyembunyikan maksud atau pereferensi mereka yang sesungguhnya.

Untuk mengetahui bagaimana JS memberitakan atau mencitrakan baik Prabowo maupun Jokowi digunakannya analisis isi memang dimungkinkan. Namun tampaknya itu belum cukup. Sebuah teks bagaimanapun juga tidak dapat berdiri sendiri, melainkan ada konteks/kondisi/situasi yang diacu untuk mengkonstruksi wacana tersebut. Oleh karena itu, untuk mengkaji teks yang bisa dihubungkan dengan konteks digunakanlah analisis wacana ini. Hanya saja kelemahan analisis wacana adalah sulit meneliti data teks yang jumlahnya sangat banyak. Maka dengan dugunakannya analisis ini tidak semua artikel dianalisis, melainkan dipilih satu artikel secara random terutama artikel yang melalui hasil pembacaan menyeluruh paling mencerminkan preferensi, sikap dari JS.

Model analisis wacana yang akan digunakan adalah dengan meminjam analisis wacana model Van Dijk, yaitu dengan mengkaji wacana dari tiga sisi: sisi konteks (situasi dimana teks itu muncul), kognitif sosial (peran media massa), dan teks (artikel yang diproduksi). Penelilitan ini hanya memfokuskan pada analisis teks, yang terdiri dari struktur makro (topik), superstruktur (paragraf dan pokok pikiran), dan struktur mikro (semantik, stilistik, retoris, dan sintaksis) (Eriyanto, 2006: 225).

Jurnal Lakon: Kajian Sastra dan Budaya 
Jurnal Lakon, 5 (1) 2016

(63-81)

\begin{tabular}{|c|}
\hline Judul \\
\hline 民主改革の前進か後退か 大統領選が問うもの $\quad(2014$ 年 06 月 10 日) \\
\hline Paragraf 1 \\
\hline 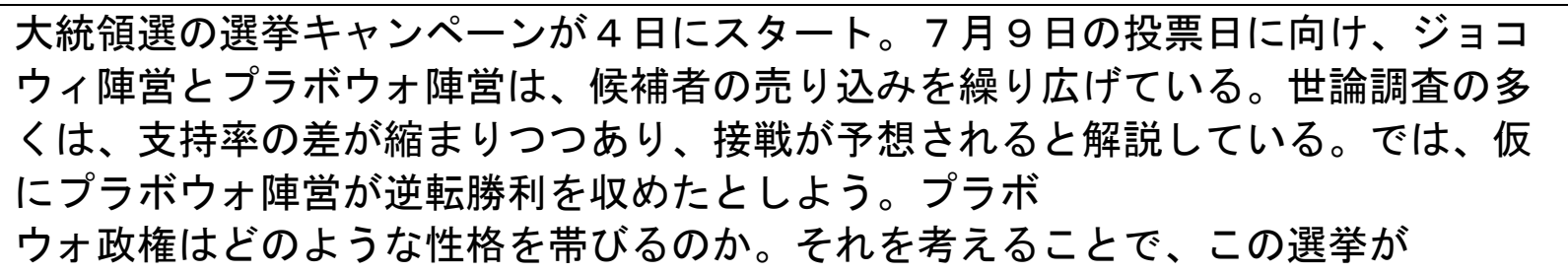 \\
\hline
\end{tabular}

Artikel yang akan dianalisis dengan analisis wacana model Van Dijk adalah sebagai berikut: 
インドネシアにとっていかに大事な選択になるかを浮き彫りにしてみよう。

Paragraf 2

プラボウォ政権なら五つの政党の連合がプラボウォ＝ハッタの正副大統領候補を擁立 し、2人は各党と密接な関係にある社会組織の支持を受けている。

これらの勢力が、プラボウォ氏の勝利に最も貢献したとして、優遇されることになる 。それはどういう人たちか。

Paragraf 3

まず人権侵害の容疑者たちである。プラボウオ自身が過去に反政府活動家の拉致監禁 の責任で軍籍を剥奪されたのは有名だが、その拉致部隊にいた「お仲間」たちも彼の グリンドラ党や、連立に加わる開発統一党などにいる。こういった退役軍人たちは陸 軍特殊部隊の出身者が多い。この特殊部隊は、スハルト時代に秘密工作を専門にして きた。言ってみれば、旧体制における政

治弾圧の担い手であり、人権侵害のシンボルである。その人たちがプラボウォ陣営で 選挙を支えている。

\section{Paragraf 4}

民間のプレマンたちもプラボウオ支持で動いている。あのヒット映画「アクト・オブ ・キリング」に出てくる「パンチャシラ青年団」や、イスラム擁護の名の下で暴力的 なデモ活動を各地で行う白装束の集団「イスラム防衛戦線」、さらにはジャカルタの 土着民族の利益保護を訴える名目で威嚇行為を繰り広げる黒装束の「ブタウィ統一フ オーラム」。これらは皆、毎年何件も暴力事件を起こしているものの、ユドヨノ政権 の対応は弱腰だった。プラボ

ウォ政権になれば、彼らは今まで以上に存在感を増すであろう。言論や政治活動の自 由は、相当侵害される可能性が強い。

Paragraf 5

疑惑持ちの党首ずらり污職への取り組みも今以上に鈍くなろう。そもそも、プラボウ オ個人の企業が石炭や森林や製紙業界に多数あり、公職に就けば利

益相反は目に見えている。

Paragraf 6

しかも、彼の選挙陣営は疑惑の人たちが牛耳っている。例えば、プラボウォ支持を真 つ先に表明した開発統一党の党首で元宗教相のスルヤダルマ氏は、巡礼預金不正流用 の疑惑で容疑者に認定されている。ゴルカル党のバクリ一党首も、自らの財閥に絡む 污職や脱税疑惑、さらにはシドアルジョ県の泥噴出事故の補償問題などを抱える。同 じく福祉正義党の党首アニス・マッタも

贈収賄疑惑が後を絶たない。

Paragraf 7

もちろんジョコウィ支持の政治家たちが全てクリーンなわけではないが、支 持政党の党首がこぞって「疑惑持ち」というプラボウォ陣営は、やはり異様である。 選挙に勝ったら、こういう党首たちが影響力を持つことは明白で、 
dalam konteks Indonesia lebih dikenal

\begin{tabular}{|c|}
\hline それに伴い污職への取り組みが骨抜きになることは想像に難くない。 \\
\hline Paragraf 8 \\
\hline $\begin{array}{l}\text { 人権侵害や暴力、污職といった問題に寛容になることで、インドネシアの過去 } 16 \text { 年 } \\
\text { の民主改革が大きく後退する可能性がある。察の総選挙でバクリー氏がゴルカ } \\
\text { ル党のキャンペーンで訴えたことは、スハルト時代のロマンティシズムだった。いわ } \\
\text { ば確信犯であり、彼がプラボウオ政権下では最大 } \\
\text { 与党のボスとして影響カを保持する。 }\end{array}$ \\
\hline Paragraf 9 \\
\hline $\begin{array}{l}\text { もちろん有権者の投票基準は様々で争点も多々あろう。しかし、権力闘争のカ学から } \\
\text { 見て、確かなことはーつである。それは主改革の後退か、それとも前進を期 } \\
\text { 待するのか、重大な岐路に立っているということである。 } \\
\text { (本名純・立命館大学国際関係学部教授) }\end{array}$ \\
\hline
\end{tabular}

dengan istilah "Reformasi" saja.

Sumber: The Daily Jakarta Shinbun Online. 2014. 民主改革の前進か後退か 大統領選が問うもの (2014

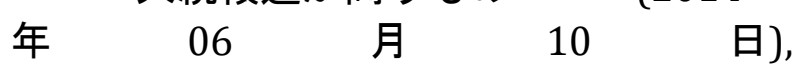
http://www.jakartashinbun.com/member/ detail/18960.html. diakses 1 Juni 2015.

Artikel ini dipilih atas pertimbangan karena terlihat memiliki kencenderungan tendensius kepada salah satu calon presiden. Hal itu dapat diketahui dari hasil pembacaan seluruh 56 artikel JS, bahwa sebagian besar artikel JS terkait pilpres bernuansa tendensius, dan yang dipilih ini merupakan yang paling tendensius dibanding yang ada. Diharapkan dengan dasar pertimbangan tersebut dapat dimunculkan hipotesa terhadap keseluruhan artikel.

Dilihat dari struktur makro (judul dan topik) artikel, judul artikel ini dapat dikatakan cukup obyektif dan netral karena tidak menampilkan baik nama Jokowi dan Prabowo. Yang tampak ingin diangkat oleh JS adalah permasalahan “民主改革” (minshu kaikaku/Reformasi Demokratik) yang
JS tampak menaruh perhatian pada permasalahan "reformasi". Meskipun dua istilah ini (reformasi dan reformasi demokratik) sedikit berbeda karena ada kosa kata "demokratik", namun keduanya mengacu pada realita yang sama yaitu peristiwa "Gerakan Reformasi tahun 1998" yang memiliki agenda "membuat Indonesia lebih demokratis". Tidak berhenti di situ, kalimat pada judul ini masih diteruskan dengan kalimat berikutnya "大統領選が問 うもの”/daitouryou ga tou mono yang artinya "hal-hal yang perlu dipertanyakan dari pilpres". Jadi judul ini ingin mengajak pembaca kritis bahwa ada hal-hal yang perlu ditanykan atau dikritisi terkait dengan pemilu presiden kali ini, terutama sejauh mana membuat agenda reformasi lebih maju.

$$
\text { Melalui pembacaan secara }
$$
mendalam dan menyeluruh, diketahui bahwa artikel ini justru secara dominan memberitakan Prabowo. Hampir sebagian besar teks berisi fakta tentang Prabowo, yang intinya adalah fakta tentang orang atau tokoh yang ada di baliknya yang

Jurnal Lakon: Kajian Sastra dan Budaya e-ISSN: 2527-4899; p-ISSN 2252-8954 
kebanyak tersangka korupsi, preman, dan lain-lain. Dengan kata lain, bila disederhanakan inti isi dari artikel ini adalah: "fakta negatif tentang Prabowo". Hanya satu saja nama Jokowi muncul, sisanya sebagian besar Prabowo. Jadi, artikel ini, dari sisi topik secara keseluruhan bernuansa didominasi oleh fakta tentang "Prabowo" terutama fakta negatif tentangnya. Hanya saja, jika tidak ada citra positifnya, perlu dicari bagaimana hal itu dikonstruksi ke dalam teks.

Untuk itu, dibawah dilakukan tahap analisis berikutnya yaitu analisis superstruktur dengan jalan mencari pokok pikiran dari masing masing paragraf artikel di atas, yang hasilnya adalah sebagai berikut:
Dari tabel tersebut, dapat diketahui bahwa pokok pikiran masing masing paragraf didominasi fakta tentang Prabowo, terutama fakta mengenai orang-orang yang ada dibalik Prabowo yang terdiri dari mantan Kopasus yang menjadi tersangka HAM, tokoh partai tersangka korupsi, dan preman. Tampak bahwa, ada nama Prabowo di setiap paragraf, dan dari serangkaian fakta positif dan negatif tentang Prabowo tersebut, wartawan tampak lebih mengangkat fakta-fakta negatif tentang Prabowo untuk dijadikan pokok bahasan dalam teks. Dari sini terlihat, dari sisi superstruktur, bagaimana tendensi wartawan JS yang lebih mendiskreditkan Prabowo telah dapat ditangkap. Selanjutnya, dilihat dari struktur mikronya, pada paragraf pertama, tak terbaca tendensi wartawan pada satu capres. Pada paragraf tersebut dua nama

\begin{tabular}{|c|c|}
\hline Paragraf & Pokok Pikiran \\
\hline 1 & $\begin{array}{l}\text { Kubu Prabowo dan Jokowi berlomba menjual calonnya. Selisih Tingkat } \\
\text { dukungan mengecil }\end{array}$ \\
\hline 2 & $\begin{array}{l}\text { Peran dan Dukungan besar partai koalisi pada prabowo. Namun } \\
\text { kapasitasnya perlu dipertanyakan. }\end{array}$ \\
\hline 3 & $\begin{array}{l}\text { Anggotanya adalah para tersangka HAM, pensiunan kopasus satu korps } \\
\text { masa aktif jaman Suharto. }\end{array}$ \\
\hline 4 & $\begin{array}{l}\text { Prabowo juga didukung para preman, yang akan meningkat eksistensinya } \\
\text { kalau ia jadi presiden. }\end{array}$ \\
\hline 5 & $\begin{array}{l}\text { Usaha kepala partai utk korup makin gencar. Prabowo memiliki bidang } \\
\text { usaha banyak, bila ia menjabat, profitnya akan meningkat. }\end{array}$ \\
\hline 6 & $\begin{array}{l}\text { Kubu koalisi prabowo banyak dipimpin tokoh tersangka (korupsi). Suryadarma } \\
\text { korupsi dana pajak, bakri korupsi pajak, anis matta tersangka } \\
\text { korupsi. }\end{array}$ \\
\hline 7 & $\begin{array}{l}\text { Kekawatiran kalau prabowo menang, kubunya akan leluasa korup, dan } \\
\text { korupsi akan sulit diberantas.) }\end{array}$ \\
\hline 8 & $\begin{array}{l}\text { Kekawatiran Indonesia akan kembali ke masa } 16 \text { tahun yang lalu bila dipenuhi } \\
\text { masalah korupsi, kekerasan dan pelanggaran HAM. Kekawatiran } \\
\text { munculnya kembali romantisisme Suharto. Apalagi Bakri dengan } \\
\text { Golkarnya di bawah Prabowo. }\end{array}$ \\
\hline 9. & $\begin{array}{l}\text { Kesimpulan, pilpres memang penuh persaingan, tetapi yang paling penting apa } \\
\text { yang diharapkan, akankah cita-cita reformasi maju atau } \\
\text { mundur, saat ini ada di persimpangan jalan. }\end{array}$ \\
\hline
\end{tabular}


capres sama-sama disebut. Latar yang ditampilkan netral adanya. Sehingga dapat disimpulkan paragraf ini memberitakan dua capres secara obyektif dan netral.

Pada paragraf kedua, mulai terlihat tendensi JS pada Prabowo. JS mulai membahas bahwa Prabowo yang didukung oleh koalisi 5 partai besar. Paragraf diakhiri dengan kalimat tanya: “それはどういう人 たちか” (seperti apakah sosoknya?). Dalam sebuah teks artikel berita khususnya berita hard news, meski tidak salah, umumnya jarang digunakan kalimat tanya. Dengan adanya kalimat ini, pembaca tampak diajak untuk berpikir, dan bertanya-tanya "siapakah sebenarnya tokoh atau pendukung Prabowo". Sampai di sini, paragraf ini masih netral, dan ketimbang negatif lebih cenderung mencitrakan Prabowo positif.

Pada paragraf ketiga, disinilah "tokoh-tokoh di balik Prabowo" tersebut dikuak secara rinci oleh JS. Secara eksplisit JS menyebutkan:

\section{"人権侵害の容疑者たち"}

(para tersangka pelanggar HAM),

“その拉致部隊にいた「お仲間」た ち” (para “sahabat” korps penculik )

JS secara berani menyebutkan secara eksplisit dan vulgar tokoh-tokoh di balik Prabowo dalam suatu artikel yang sifatnya hard news. Tokoh-tokoh yang disebutkan ternyata bukan tokoh-tokoh yang memiliki citra positif melainkan sebaliknya. Para pelanggar HAM bagaimanapun juga merupakan tokoh bercitra buruk. HAM adalah permasalahan yang sensitif, dan pelakunya tidak hanya disukai tetapi juga harus dihukum. Sebenarnya patut dipertanyakan, dari sekain banyak tokoh yang memiliki citra positif di sekeliling Prabowo, mengapa JS memilih "tokoh pelanggar HAM", sehingga terasa ada seleksi isu dan fakta di sini.

Tokoh ini ternyata masih dirinci kembali secara detil, yaitu merupakan tokoh yang terlibat dalam "penculikan aktivis mahasiswa" yang akhirnya masuk menjadi anggota partai Gerindra. Terlebih Prabowo sendiri juga diceritakan secara detil bahwa:

“プラボウォ自身が過去に反政府活 動家の拉致監禁の責任で軍籍を剥奪され たのは有名だが。。”

(Prabowo sendiri, dikenal telah diberhentikan dari militer sebagai bentuk tanggungjawab terhadap penculikan dan penahanan aktivitis anti pemerintah masa lalu").

Penculikan, dipecat dari militer adalah citra yang buruk. Muncul pertanyaan mengapa dari serangkaian kisah hidup Prabowo yang baik, kisah saat kelam tahun 1998-lah yang dipilih. Bila benar demikian, mengapa kosa kata yang dipilih adalah kosa kata yang amat eksplisit menggambarkan perilaku yang buruk, seperti:

“人権侵害” (pelanggaran HAM) dan

\section{"反政府活動家の拉致監禁"}

(penculikan dan penahanan aktivis anti pemerintah).

Bukankan ada kosa kata lain yang lebih netral, misanya HAM diganti dengan hukum, menjadi "pelanggaran hukum" atau penculikan dan penahanan aktivis 
pemerintah menjadi "melakukan tindakan di luar wewenangnya". Jadi terlihat kembali ada seleksi dan pemililhan fakta di sini, dilanjutkan pemilihan kosa kata oleh wartawan JS, yang kesemuanya mencitrakan negatif Prabowo.

Pada paragraf ke empat, sama halnya dengan paragraph ketiga, dirinci kembali anggota koalisi Prabowo. Sekali lagi, dari sekian anggota yang baik, namun anggota yang memiliki citra buruklah yang disebutkan yaitu:

\section{“民間のプレマンたちもプラボウォ} 支持で動いている” (Para preman swasta pun mendukung Prabowo).

Kembali JS menyebutkan secara vulgar dan eksplisit pendukung Prabowo dengan kata “プレマンたち” (para preman). Lebih rinci, JS menyebutkan bahwa para preman tersebut diantaranya adalah:

“「パンチャシラ青年団」や、イス ラム擁護の名の下で暴力的なデモ活動を 各地で行う白装束の集団「イスラム防衛 戦線」”

(Organisasi Pemuda Pancasila, dan Front Pembela Islam, organisasi dengan baju putih yang melakukan demo dengan kekerasan di macam tempat mengatasnamakan melindungi Islam).

Preman dalam kehidupan tengah masyarakat Indonesia dikenal sebagai orang yang mengganggu, sering memalak dan mengancam. Intinya orang yang meresahkan masyarakat. Juga disampaikan kekawatiran bila Prabowo menjadi presiden, maka para preman ini makin kuat. Paragraf ini kembali menegaskan kembali, tendensi dan preferensi JS yang memberitkan negatif Prabowo. JS telah berani menggunakan kata "preman" yang dalam konteks Indonesia bercitra negatif apalagi disematkan pada tokoh capres Prabowo.

JS tampak mendiskreditkan Prabowo, apalagi dengan ditutupnya paragraf ini dengan kekawatiran:

“プラボウォ政権になれば、彼らは 今まで以上に存在感を増すであろう。言 論や政治活動の自由は、相当侵害される 可能性が強い”

(kalau Prabowo berkuasa, eksistensi mereka (preman) akan menguat. Kebebasan berpendapat dan berpolitik kemungkinan besar akan terancam).

Sebuah penyimpulan yang tampak mengarahkan pemikiran pembaca agar jangan memilih Prabowo sebagai presiden. Karena bila ia terpilih, eksistensi para preman akan menguat, akibatnya kebebasan berpendapat dan berpolitik akan terancam. Hal ini sangat tendensius karena semua itu belum terjadi, namun diasumsikan seolah-olah terjadi, asumsi yang belum tentu kebenarannya. Jadi dalam paragraf ini JS kembali memberitakan negatif Prabowo.

Pada paragraf kelima, isinya masih serupa, yaitu seputar kegiatan korupsi para tersangka korupsi ketua partai kubu Prabowo yang makin gencar. Juga mengenai profit usaha Prabowo yang akan makin besar bila ia nanti menjadi presiden. JS kembali mencitrakan negatif Prabowo dengan menggunakan pengandaian: 
ている。”

“公職に就けば利益相反は目に見え

(Bila (Prabowo) menduduki jabatan publik, keuntungan (usahanya) akan terlihat)

JS berasumsi dengan menggunakan pengandaian untuk hal yang belum tentu benar ini, pemikiran pembaca digiring untuk tidak memilih Prabowo. Dengan demikian pada Paragraf ini JS kembali mencitrakan negatif Prabowo.

Pada paragraf ke enam, seperti halnya paragraph kelima dan keempat, JS kembali merinci secara detail siapa saja anggota kubu koalisi Prabowo, yang bermasalah yaitu dengan kalimat:

“ 彼の選挙陣営は疑惑の人たちが牛 耳っている” (Kubunya (Prabowo) dikuasai para tersangka".

Kalimat ini diikuti lagi dengan penjelasan secara rinci, bahwa para tersangka tersebut ialah:

- “スルヤダルマ氏は、巡礼預金不正流 用の疑惑で容疑者” (Suryadarma tersangka penyalahgunaan dana haji),

- “ゴルカル党のバクリー党首も、自ら の財閥に絡む污職や脱税疑惑、さら にはシドアルジョ県の泥噴出事故の 補償問題などを抱える”

(Bakri sebagai ketua partai golkar, korupsi pajak dan korupsi yang melibatkan kelompok bisinisnya, dan memiliki masalah ganti rugi korban lumpur Sidoarjo),

- “同じく福祉正義党の党首アニス． マッタも贈収賄疑惑が後を絶たない.
(Anis Matta, ketua PKS tersangka uang sogok).

JS benar benar menyebutkan secara eksplisit baik nama, jabatan, dan apa yang dilakukan tokoh tersebut, yang sebenarnya dalam pemberitaan dapat disingkat namanya untuk menghindari "praduga tak bersalah". Namun, ternyata tidak. Bisa diasumsikan hal ini dikarenakan pangsa pembaca bukanlah orang Indonesia, sehingga tidak ada kekawatiran terjadinya kecanggungan psikologis.

Jadi pada paragraph ini jelas JS secara eksplisit telah mendiskreditkan dan mencitrakan negatif Prabowo. Paragraf ini menambah daftar panjang mengenai tokoh dan orang yang bermasalah di kubu Prabowo seperti pada paragraf sebelumnya. Kesimpulannya paragaf ini JS kembali mencitrakan negatif Prabowo.

Pada paragraf ketujuh, berisi kekawatiran JS bilamana Prabowo menjadi presiden. Yang menarik di paragraf ini nama Jokowi disebut, dengan mengatakan:

“もちろんジョコウィ支持の政治家 たちが全てクリーンなわけではないが、 支持政党の党首がこぞって「疑惑持ち」 というプラボウォ陣営は、やはり異様で ある。”

(tentu saja politikus pendukung Jokowi tidak seluruhnya bersih, namun kubu Prabowo yang terdiri dari (tersangka) para ketua partai pendukung adalah (orang-orang) yang aneh).

Kalimat inilah yang seharusnya lebih dirinci dan dielaborasi lebih dalam lagi oleh JS terutama terutama tentang orang-orang di balik kubu Jokowi sebagai penyeimbang penjelasan tentang Prabowo. Namun 
nyatanya tidak. Sebaliknya, Jokowi terkasan justru dibela dengan mengatakan "kalau politikus pendukung Jokowi bukan berarti semuanya bersih, namun pendukung Prabowo jelas orang-orang yang aneh". Terasa ada semacam pengalihan isu di sini. Semestinya yang dibahas Jokowi, namun mengapa melompat membahas kalau pendukung Prabowo adalah orang yang aneh. Seharunya yang dibahas, kalau memang tidak semua pendukung Jokowi bersih, maka bagaimana solusinya. "Aneh" yang diterjemahkan dari kosa kata “異様” dalam hal ini dapat diinterpretasikan bahwa mereka bukanlah orang baik-baik.

Pada paragraf ini pula, pembaca digiring JS untuk tidak memilih Prabowo dengan menggunakan kalimat pengandaian:

“選挙に勝ったら、こういう党首た ちが影響力を持つことは明白で、それに 伴い污職への取り組みが骨抜きになるこ とは想像に難くない”

(Bila menang dalam pemilu, maka jelas ketua partai tersebut akan memiliki kekuatan pengaruh, dan seiring dengan itu sulit dibayangkan pemberantasan korupsi dapat menyentuh akarnya).

JS tampak jelas tidak imbang dalam memberitakan Jokowi dan Prabowo. Jokowi diberi porsi yang kecil dan terkesan dibela, sementara Prabowo diberi porsi yang besar dan terkesan dideskreditkan. Kemudian, pembaca digiring agar tidak memilih Prabowo.

Pada paragraf ke delapan, sama dengan paragraf ke tujuh, berisi kekawatiran JS bila Prabowo menjadi presiden. JS menyatakan:
“人権侵害や暴力、污職といった問 題に寛容になることで、インドネシアの 過去 16 年の民主改革が大きく後退する 可能性がある” (Dengan ditolerirnya permasalahan korupsi, kekerasan, dan pelanggaran HAM, maka ada kemungkinan cita-cita Reformasi Indonesia 16 tahun yang lalu akan mengalami kemunduran besar)

JS kembali menggiring pembaca dengan memunculkan kekawatiran bila korupsi, pelanggaran HAM, ditolerir maka reformasi (demokratik) akan mundur ke belakang. JS juga memunculkan kekawatiran akan munculnya romantisme Suharto. Padahal itu semua belum tentu benar dan hanya sebatas asumsi.

Artinya, JS mengajak pembaca agar hati-hati untuk memilih Prabowo sebagai presiden. Karena kalau itu terwujud, akan terjadi hal-hal yang dikawatrikan JS sebelumnya. Dari sini JS tampak berlebihan dalam memunculkan dugaan, karena itu semua sebenarnya baru sebatas asumsi, dan belum tentu terjadi.

Terakhir pada paragraf ke delapan, yaitu ditutup dengan mengajak pembaca untuk memikirkan kembali sejauh mana pilpres ini mendukung cita-cita reformasi yaitu dengan menyatakan bahwa:

“それは民主改革の後退か、それと も更なる前進を期待するのか、重大な岐 路に立っているということである”

(Bahwa saat ini (kita) sedang ada di persimpangan jalan, akan berharap maju atau mundurkah reformasi demokratik).

Artinya JS mengajak pembaca bahwa saat ini Indonesia ada dalam persimpangan jalan, dan bila salah pilih akibatnya bisa fatal, yaitu terjadinya kemunduran cita-cita

Jurnal Lakon: Kajian Sastra dan Budaya

e-ISSN: 2527-4899; p-ISSN 2252-8954 
reformasi-demokratik atau “民主改革”, alias Indonesia bakal tidak akan menjadi negara yang demokrasi lagi, sehingga untuk itu, perlu hati-hati untuk memilih Prabowo karena berbagai kekawatiran seperti yang dipaparkan pada paragraf sebelumnya.

Namun asumsi tersebut diragukan karena di dalam anggota koalisi kubu Prabowo ada Partai Amanat Nasional dengan ketua dewan pembinanya adalah Amien Rais yang notabene adalah mantan aktivis reformasi 1998. Jadi asumsi-asumis JS tersebut kurang beralasan. Akhirnya, dapat disimpulkan bahwa dari analisis wacana terhadap artikel dengan judul di atas, konstruksi wacana yang dilakukan JS tidak obyektif, tendensius, dan mendiskreditkan Prabowo. Hal ini didasarkan atas hasil analisis bahwa;

Pertama; sebagian besar pokok pikiran di atas berisi fakta tentang Prabowo. Nama Prabowo disebut 12 kali, dan Jokowi disebut 2 kali. Kedua, dari serangkaian fakta baik positif maupun negatif terkait dengan Prabowo, wartawan JS lebih memilih fakta-fakta atau isu negatif untuk dikonstruksi menjadi artikel di atas yaitu tentang tokoh politik yang tersangka korupsi, pelanggaran HAM, dan lain-lain. Padahal kalau mau diperiksa, tokoh-tokoh yang baik, bersih yang ada di kubunya juga cukup banyak seperti Amien Rais, Mahfud $\mathrm{MD}$, dan lain-lain, namun tidak disinggung sama sekali. Ini menunjukkan bagaimana preferensi wartawan, bahwa wartawan lebih mendiskreditkan dan mencitrakan buruk Prabowo daripada Jokowi.

Ketiga, JS tidak seimbang dalam memberitakan Prabowo, karena Jokowi tidak dibahas dengan porsi yang sama. Bila JS membahas mengenai tokoh-tokoh bermasalah di dalam kubu Prabowo, semestinya JS juga membahas tokoh yang sama dari kubu Jokowi. Namun kenyataannya tidak. Bahka bila dicari di artikel lain tidak ada sama sekali artikel yang membahas tokoh bermasalah pada kubu Jokowi. Ini menunjukkan JS lebih cenderung mendiskreditkan Prabowo.

Keempat, selain membahas tokoh bermasalah, JS juga memilih kata-kata yang bercitra negatif seperti "Pelanggar HAM", "tersangka korupsi", "penculik aktivis mahasiswa anti pemerintah" untuk menggambarkan para tokoh di balik kubu Prabowo. Meski tidak ditujukan lagsung pada Prabowo, namun karena untuk menggambarkan tokoh di balik Prabowo, maka dengan sendirinya tetap menunjuk Prabowo, dan hal ini sama saja mencitrakan Prabowo negatif.

\section{KESIMPULAN}

Dari serangkaian bermacam analisis diatas dapat disimpulkan bahwa: (1) Melalui analisis isi, JS mengangkat tema tentang Prabowo dan Jokowi secara berimbang. Jumlah keseluruhan tema yang terkait dengan masing-masing tokoh diangkat hampir sama. Hanya saja bila ditinjau isi dari masing-masing pokok pikiran di tiap paragraf, JS tampak menampilkan tema yang memberitakan negatif Prabowo jauh lebih banyak daripada Jokowi. Jumlah tema yang memberitkan negatif Prabowo yaitu sebanyak 14 tema, sementara Jokowi yang hanya 2 tema saja. Dari sini dapat diraba sikap dan preferensi JS, bahwa media ini lebih mendiskreditkan Prabowo, yang bisa diartikan juga lebih pro kepada Jokowi; (2)Melalui analisis wacana, diketahui bahwa dalam saslah satu artikel JS tidak berimbang dalam memberitakan Prabowo dan Jokowi. JS lebih banyak mengangkat 
fakta-fakta negatif tentang Prabowo, sementara tidak dengan Jokowi. Fakta negatif tentang Jokowi sedikit atau tidak ada sama sekali. Kedua, JS menggunakan kata-kata yang vulgar dan eksplisit dalam memberitakan Prabowo seperti "tersangka HAM", "tersangka korupsi", "penculikan aktivis", "dipecat dari militer", dan seterusnya. Selain itu, JS juga hanya mengangkat tokoh-tokoh bermasalah pada kubu Prabowo dengan menyebut nama, namun tidak demikian dengan kubu Jokowi.

Dengan demikian, artikel ini berisi berita yang lebih mencitrakan negatif dan mendiskreditkan Prabowo. Meski tidak bisa digunakan untuk menggeneralisir bahwa itu juga tercermin dari keseluruhan artikel, namun atas artikel ini bisa dimunculkan hipotesa bahwa JS tidak pro pada Prabowo, dan bisa diinterpretasikan lebih pro pada Jokowi.

\section{SIMPULAN}

Buku:

Badara, Dr. Aris, M.Hum. (2012). Analisis Wacana: Teori, Metode, Dan Penerapannya Pada Wacana Media. Jakarta: Kencana Prenada Media Group.Baehaqie, Imam. 2008. Sintaksis Teori dan Analisis. Yogyakarta: Pustaka Pelajar.

Davis, Howard dan Paul Walton. (2010). Bahasa, Citra, Media (Edisi Pertama). Yogyakarta: Jalasutra.

Eriyanto. (2001). Analisis Wacana, Pengantar Analisis Teks Media. (Cetakan I).Yogyakarta: LKiS Yogyakarta.

Eriyanto. (2011). Analisis Isi, Pengantar Metodologi untuk Penelitian Ilmu Komunikasi dan Ilmu-ilmu Sosial Lainnya (Cetakan I). Jakarta: Kencana Prenada Media Group.
Leech, G. (1992). Corpora and theories of linguistic performance. In J. Svartvik (Ed.) Directions in Corpus Linguistic, Proceedings of Nobel Symposium 82, Stockholm, 4-8 August 1991. ACM, Berlin, New York: Mouton de Gruyter.

Mc Quail, Denis. (1987). Teori Komunikasi Massa Suatu Pengantar (Edisi Kedua). Jakarta: Penerbit Erlangga.

Mondry. (2016). Pemahaman Teori dan Praktik Jurnalistik (Edisi Kedua). Bogor: Ghalia Indonesia.

Romli, Asep Syamsul M. (2012). Jurnalistik Online: Panduan Praktis Mengelola Media Online (Dilengkapi Kiat Blogger, Teknik SEO, dan Tips Media Sosial)(Cetakan I). Bandung: Nuansa Cendekia.

Website:

BBC Indonesia. (2014). Profil capres: Prabowo Subianto, dalam http://www.bbc.com/indonesia/lap oran khusus/2014/06/140626 laps us pilpres profil_prabowo, diakses 22 Juli 2016.

BBC Indonesia. (2014). Profil capres: Joko Widodo, dalam http://www.bbc.com/indonesia/lap oran khusus/2014/06/140626 laps us pilpres profil_jokowi, diakses 22 Juli 2016.

BBC Indonesia. (2014). KPU tetapkan Jokowi menang di pilpres, dalam http://www.bbc.com/indonesia/ber ita indonesia/2014/07/140722 kpu hasil pilp res, diakses 22 Juli 2016.

BBC Indonesia. (2014). Pilpres 2014: Ketika media jadi corong propaganda, dalam http://www.bbc.com/indonesia/ber ita indonesia/2014/07/140702 lap sus media bias, diakses 22 Juli 2016.

Jurnal Lakon: Kajian Sastra dan Budaya e-ISSN: 2527-4899; p-ISSN 2252-8954 
Jurnal Lakon, 5 (1) 2016

(63-81)

The Daily Jakarta Shimbun Online. (2014).

http://www.jakartashimbun.com/m

ember/detail/18922.html, diakses 1

Juni 2015.

Jurnal Lakon: Kajian Sastra dan Budaya e-ISSN: 2527-4899; p-ISSN 2252-8954 